\title{
Coordinating Macroprudential Policies within the Euro Area: The Case of Spain
}

\author{
Margarita Rubio* \\ University of Nottingham
}

\author{
José A. Carrasco-Gallego ${ }^{\dagger}$ \\ University of Portsmouth
}

June 2016

\begin{abstract}
In the aftermath of the global financial crisis, there is consensus on the need for macroprudential policies to promote financial stability. However, the optimal way to implement such policies in the Euro area is a question open to debate, given that countries have to coordinate. In this paper, we propose a two-country, two-sector monetary union dynamic stochastic general equilibrium model (DSGE) with housing to analyze the optimal implementation of macroprudential policies in the Euro area. Currently, Spain is the only country within the EU that has not established a macroprudential regulator. We use Spain as a natural experiment to study the effects of a lack of coordination in the use of macroprudential policies in the European Monetary Union (EMU). We focus on a particular macroprudential policy, a rule regarding the loan-to-value ratio, which responds countercyclically to credit booms. We find that such a policy is welfare enhancing for the Euro area. Nevertheless, if one country does not implement the policy, but the rest of the EMU does, as in the current situation with Spain, this country still yields some benefits as a result of its partners' implementation of the policy because it gains from a more stable financial system without incurring any output costs. However, if all Euro countries actively implement the policy, the welfare gains for all of them are larger.

Keywords: Macroprudential policy, coordination, loan-to-value ratio, welfare, Euro area, Spain. JEL Classification: E32, E44, E58
\end{abstract}

\footnotetext{
${ }^{*}$ University of Nottingham, Sir Clive Granger Building, University Park, Nottingham, NG7 2RD, UK. E-mail: margarita.rubio@nottingham.ac.uk.

${ }^{\dagger}$ Portsmouth Business School Portland Street, Richmond Building, Portsmouth, PO1 3DE, UK. E-mail. jose.carrascogallego@port.ac.uk.
} 
"[...] The entry into force of the new EU prudential rules for banks on 1 January 2014 gives the macro-prudential authorities in the EU a new set of policy instruments to address financial stability risks more effectively. This will establish a common legal framework for macro-prudential policy across the EU. However, the application of macro-prudential policy is still in its infancy. Much of the analytical framework has yet to be developed." Mario Draghi, March 2014

\section{Introduction}

After the recent financial crisis, a new set of economic policies was developed and referred to as macroprudential policies. The main objective of these policies is to prevent excessive credit growth and systemic risk. ${ }^{1}$ Although there is consensus on the need for such policies, the best way to implement these policies in a monetary union is still a question that is open to debate. The first issue that arises is whether these policies should be implemented centrally or at a national level. If they are set on a national basis, the next question is how their implementation should be coordinated with other countries in the union that are also implementing such policies. If there is no coordination, i.e., if one country does not apply the same set of policies as the rest of the monetary union, this may have important implications for welfare, financial stability, and the functioning of the area.

When one country within a monetary union implements macroprudential policies, positive effects on financial stability may spill over to other countries that are not implementing them. This could lead to some accidental and unwanted consequences, including leakages and regulatory arbitrage, as well as external effects on other member states and an uneven playing field. To alleviate these unintended consequences, coordination and reciprocity are required between national macroprudential authorities. In this context, coordination means that, within the monetary union, a member state applies to its own institutions the same or an equivalent macroprudential measure to that set by another member state.

In the European Union (EU), the European Systemic Risk Board (ESRB) is the main body responsible for monitoring macroprudential policies, although each country can implement its own policy. ${ }^{2}$ That is, macroprudential policies are implemented at a national level, but within a system of central supervision. Along these lines, the ESRB recommended in 2011 that Member States should designate a national authority entrusted with the conduct of macroprudential policy. ${ }^{3}$ In the last Annual Report,

\footnotetext{
${ }^{1}$ See IMF (2011).

${ }^{2}$ The ESRB was established in 2010 as a component of the European System of Financial Supervision (ESFS). See Section 3 for more details.

${ }^{3}$ See ESRB (2011).
} 
ESRB (2014a), the Board concluded that very different levels of accomplishment of the 2011 Recommendation existed. In particular, it observed that 27 out of 28 EU members had already established their national macroprudential competent supervisory authorities. The only country that remains without a competent macroprudential supervisory authority, and that has not implemented a macroprudential policy under the ESRB regulatory framework, is Spain. This represents an example of noncoordination in these type of policies; therefore, the case of Spain provides a perfect natural experiment to study the economic consequences of a lack of coordination in the implementation of a macroprudential instrument in a currency area; i.e., it is an example of the case where one country does not apply a macroprudential instrument that is being used by the rest of the area.

The aim of this paper is to analyze the implications of a lack of coordination in implementation of a macroprudential instrument between one country within the currency area and the rest of the countries, and to compare it with the consequences of coordination, when a country commences implementation of the macroprudential instrument that has already been implemented by the rest of the currency area. Therefore, this paper considers two situations: first, the situation corresponding to the current state of affairs, in which one country, Spain, has not implemented a macroprudential policy but the rest of the Euro area has done so; and second, we forecast the situation where this country coordinates with the rest of the union and puts in place a new macroprudential policy.

To achieve this goal, we propose a two-country, two-sector monetary union DSGE model ${ }^{4}$ with housing and collateral constraints, allowing for cross-country differences in mortgage and housing markets. In each country, there is a group of individuals that are credit constrained and need housing collateral to obtain loans. Countries trade goods and savers in each country have access to foreign assets. In our model, one of the countries is calibrated to represent the Spanish economy, our natural experiment, whereas the other country in the model represents the rest of the Euro area. The model is appropriately calibrated to reflect the basic features of the Spanish economy, i.e., a loan-to-value (LTV) ratio that is larger than average, variable rate mortgages, a GDP that is $10 \%$ of the Euro area's total GDP and higher housing wealth as a proportion of GDP.

The basic modeling framework in this paper follows Rubio (2014), although we add macroprudential measures. Our paper relates to different strands of the literature. The model constitutes a two-country, two-sector version of the seminal paper of Iacoviello (2005), which introduces a financial accelerator

\footnotetext{
${ }^{4}$ As Gerke et al. (2013) point out, this type of model is widely used by the national central banks of the European System of Central Banks (ESCB). Although the different national banks capture country-specific characteristics and their models differ in some respects, the models share some commonalities regarding their overall setup.
} 
that works through the housing sector, in line with Aspachs and Rabanal (2010). However, this paper introduces cross-country housing market heterogeneity, as in Rubio (2014). In addition, this paper is related to the recent literature on macroprudential and monetary policies in Iacoviello-type models, including Kannan et al. (2012) and Rubio and Carrasco-Gallego (2014). Finally, it is connected to the literature on calibrated DSGE models for Spain, including Andrés et al. (2013), Ortega et al. (2011), and Mora-Sanguinetti and Rubio (2014). However, none of these models consider the study of macroprudential policies in Spain in relation to the rest of the Euro area.

In this paper, we evaluate an LTV rule as the relevant macroprudential instrument, considering the comments of the ESRB, which believes that this instrument is suitable for avoiding credit booms in real estate markets, which create substantial risks to financial stability. ${ }^{5}$ In particular, we analyze the implementation of a rule for the LTV ratio, where the rule is analogous to how monetary policy is conducted. We assume that, in the same way that the central bank follows a Taylor rule for monetary policy, the macroprudential authority follows a linear rule in carrying out macroprudential policy, using the LTV ratio as an instrument. The monetary policy literature has shown that simple rules result in good performance. Therefore, it seems sensible to apply this kind of rule to macroprudential supervision (see Yellen, 2010). ${ }^{6}$ We consider a rule for the LTV ratio that means it responds to deviations of credit from the steady state. In this way, booms that lead to an increase in borrowing are moderated. ${ }^{7}$ To reflect the recommendations of the ESRB, we consider that the macroprudential rule is implemented at a national level.

Using this modeling framework, we shed some light on the effects of a lack of coordination in the use of macroprudential policies in the Euro area, taking the case of Spain as an example. That is, taking monetary policy as given, we calculate the optimal implementation of the macroprudential rule in the rest of the Euro area, when macroprudential policies are not active in Spain. This case represents the current situation in the Euro area. Then, we look at the counterfactual of coordination, when Spain also implements macroprudential policies, and we compute the optimal macroprudential rule for both

\footnotetext{
${ }^{5}$ ESRB (2014) considers that this macroprudential instrument can be implemented by national authorities targeting borrowers to increase the resilience of both banks and borrowers.

${ }^{6}$ We can find other examples of LTV ratio rules in the literature. Funke and Paetz (2012) use a nonlinear rule for the LTV ratio and find that it can help reduce the transmission of house price cycles to the real economy. In a similar way, Kannan et al. (2012) examine a monetary policy rule that reacts to prices, output, and changes in collateral values with a macroprudential instrument based on the LTV ratio. Lambertini et al. (2013) allow for the implementation of both interest rate and LTV ratio policies in a model with news shocks.

${ }^{7}$ The IMF (2013) states that a macroeconomic environment that gives rise to credit growth will contribute to the build-up of systemic risk.
} 
regions. This represents a future case. ${ }^{8}$ We calculate the welfare associated with each case for each agent in the economy, for each country, and for the whole union. In addition, we show how the dynamics of the economy under expansionary shocks are different in each situation.

Our results show that macroprudential policies are welfare enhancing for the Euro area because they promote financial stability. However, the welfare gain is larger if all countries in the monetary union implement the policies, i.e., if there is coordination. We find that if Spain does not implement macroprudential policies, but the rest of the union does, as in the current situation, then Spain benefits slightly from its partners' policies because it can enjoy a more stable financial system without incurring any output costs. However, if both regions, Spain and the rest of the union, have active macroprudential policies, then the welfare gains are larger. In terms of the dynamics, we present impulse responses to different shocks that generate a credit boom in the economy: a productivity shock, a housing demand shock, and an expansionary monetary policy shock. We find that, given the expansionary nature of these shocks, credit increases. However, when the country has an active macroprudential rule in place, the LTV ratio declines and the credit boom is mitigated.

These results have important implications in terms of policy. If the ESRB wants to increase financial stability in the whole monetary union and maximize the union's welfare, it should lead union members towards a coordinated implementation of macroprudential policies.

The contribution of this paper is twofold. First, we provide a DSGE setting for studying macroprudential policy implementation in a country within a monetary union, in interaction with its partners. Then, within this setting, we are able to answer a specific research question: what are the consequences of the lack of coordination of one of the countries (namely Spain) and, conversely, the implications of potential coordination? These are the novel and worthwhile contributions of our paper.

The paper is organized as follows. Section 2 presents an overview of the current institutions in charge of the implementation of macroprudential policy in the EU. Section 3 describes the model. In Section 4, we determine the optimal macroprudential policy and the associated dynamics. Section 5 concludes the paper.

\footnotetext{
${ }^{8}$ It is expected that Spain will eventually put in place a macroprudential authority.
} 


\section{Macroprudential Policy in the EU}

The ESRB is responsible for the macroprudential oversight of the EU's financial system and contributes to the prevention or mitigation of systemic risks to financial stability arising from developments within the financial system. ${ }^{9}$ It should contribute to the smooth functioning of the internal market and, thereby, ensure that the financial sector plays a role in fostering sustainable economic growth. ${ }^{10}$ All types of financial intermediaries, markets, and infrastructures in the $28 \mathrm{EU}$ countries may be systemically important to some degree and may be an object of analysis for the ESRB. ${ }^{11}$

As stated in the Introduction, the ESRB recommends that EU Member States should designate a national macroprudential authority to be in charge of financial stability policies. ${ }^{12}$ To date, 27 of the 28 EU members have already appointed macroprudential authorities. All these countries have followed one of three models for establishing the authorities in charge of the implementation of macroprudential policies at the national level. Nine countries have given power to authorities that are separate from the central bank to implement their macroprudential policies; ${ }^{13}$ another 15 countries have delegated the implementation of macroprudential policies to their central banks; ${ }^{14}$ and three countries have decided to share the responsibility for macroprudential policy implementation between the central bank and another institution. ${ }^{15}$ However, the only country that remains without a competent macroprudential

\footnotetext{
${ }^{9}$ See EU (2010a).

${ }^{10} \mathrm{EU}$ (2010) defines systemic risk as a risk of disruption in the financial system with the potential for serious negative consequences for the internal market and the real economy.

${ }^{11}$ The ESRB was established in 2010 as a component of the ESFS, along with the European Supervisory Authorities (ESAs), comprising the European Banking Authority (EBA), the European Securities and Markets Authority (ESMA), and the European Insurance and Occupational Pensions Authority (EIOPA). The ESFS also includes the Joint Committee of the ESAs and the competent supervisory authorities in micro- and macroprudential policies of the member states.

${ }^{12}$ See ESRB (2011) Recommendation ESRB/2011/3 of the European Systemic Risk Board of 22 December 2011 on the macro-prudential mandate of national authorities (OJ C 41, 14.2.2012, p. 1)

${ }^{13}$ These nine countries and their macroprudential authorities are as follows: Austria: Finanzmarktstabilitätsgremium (Financial Market Stability Board); Denmark: Erhvervs-og Vaekstminister (Minister of Business and Growth) and Finanstilsynet (the Supervisory Diamond for banks); Finland: Finanssivalvonta (Financial Supervisory Authority); France: Autorité de Controle Prudentiel et de Résolution (Prudential Supervisory Authority); Germany: Bundesanstalt für Finanzdienstleistingsaufsicht (Federal Financial Supervisory Authority) and Ausschuss für Finanzstabilität (Financial Stability Committee); Luxembourg: Commission de Surveillance du Secteur Financier (Financial Sector Supervisory Commission); Malta: Malta Financial Services Authority; Poland: Komisja Nadzoru Finansowego (Polish Financial Supervision Authority); and Sweden: Finansinspektionen (Financial Supervision).

${ }^{14}$ These 15 countries and their central banks are: Belgium: Banque Nationale de Belgique/Nationale Bank van België (The Belgian Central Bank); Bulgaria: Bulgarian National Bank; Croatia: Hrvatska Narodna Banka (Croatian National Bank); Cyprus: Central Bank of Cyprus; Czech Republic: Česká národní banka (Czech National Bank); Estonia: Eesti Pank (Bank of Estonia); Greece: Bank of Greece; Hungary: Magyar Nemzeti Bank (Hungarian National Bank); Ireland: Banc Ceannais na hÉireann (Central Bank of Ireland); Italy: Banca d'Italia (Bank of Italy); Lithuania: Lietuvos Bankas (Bank of Lithuania); Portugal: Banco de Portugal (Bank of Portugal); Romania: Banca Naţională a României (National Bank of Romania); Slovakia: Národná banka Slovenska (National Bank of Slovakia); and Slovenia: Banka Slovenije (Bank of Slovenia).

${ }^{15}$ These three countries and their relevant institutions are: Latvia: Finanšu un kapitāla tirgus komisijas (Financial and Capital Market Commission) and Latvijas Banka (Bank of Latvia); Netherlands: De Nederlandsche Bank (The Dutch Bank) and the Rijksoverheid (Dutch government); and the UK: the Financial Conduct Authority and the Bank of England.
} 
supervisory authority is Spain. ${ }^{16}$

Spain recently suffered a huge bust in its real estate sector, which provoked an enormous downturn in the real and financial sectors. ${ }^{17}$ The recent crisis in Spain was centered in the housing sector. Easier borrowing conditions, together with speculative housing demand, gave rise to a housing bubble that burst, causing a strong recession. Spain's accession to the Euro area resulted in unprecedentedly low interest rates, which were low partly because of the good economic performance of Spain's Euro partners. Furthermore, most Spanish mortgage loans were subscribed at variable rates, referenced to the 12-month Euribor rate, which is strongly linked to the overnight rate of the European Central Bank (ECB). Such loans accounted for $91 \%$ of the Spanish market at the end of 2009, according to the ECB (2009). Mortgages set at fixed rates are available on the market, but are less popular as a result of restrictions on prepayment fees, leading to higher nominal interest rates and borrower preferences. ${ }^{18}$ All this, together with strong housing demand, brought about a house price and credit boom in Spain that was the seed of the crisis. ${ }^{19}$ This boom was one of the engines for Spain's economic growth before the bust. ${ }^{20}$ Nevertheless, once the bust commenced, the crisis hit Spain more severely than it did other developed economies because of Spain's excessive dependence on the real estate industry. ${ }^{21}$

When determining an appropriate macroprudential instrument, authorities faced serious implementation challenges, including defining their intermediate objectives and the source of the systemic risk they wanted to confront, determining the legal requirements for accomplishment, and ensuring ease of communication for policy implementation. If the intermediate objective is to mitigate and prevent excessive sectoral credit growth and leverage in the real estate market, the LTV ratio was determined to be a good option compared with other instruments that could mitigate and prevent excessive credit growth and leverage in general, including a countercyclical capital buffer, an increased own funds requirements, or

\footnotetext{
${ }^{16}$ Note that, in case of need, the Bank of Spain would act as the macroprudential authority.

${ }^{17}$ In Spain, bank branches distribute most mortgage loans (direct channel) compared with real estate developers or real estate agencies (indirect channel). Since the crisis, their participation in the market has increased significantly to cover nearly all of the mortgage market.

${ }^{18}$ See European Mortgage Federation (2012) for more information on the Spanish housing sector.

${ }^{19}$ In Spain, house prices more than doubled in the decade from 1997 to 2007, whereas in Germany, house prices fell by more than $10 \%$ after 2003. See Moro and Nuño (2012).

${ }^{20}$ See Akin et al. (2014).

${ }^{21}$ The Management Company for Assets Arising from the Banking Sector Reorganization (Sociedad de Gestión de Activos Procedentes de la Reestructuración Bancaria), known as SAREB, was created in November 2012 to clean up the Spanish institutions that were experiencing issues as a result of excessive exposure to the real estate sector. The Memorandum of Understanding (MoU), signed by the Spanish government, with its European partners, in July 2012, determined the constitution of SAREB as a condition for Spain receiving financial aid. Two hundred thousand real estate assets, valued at 50.781 billion euros, were transferred to SAREB. Of these assets, $80 \%$ were loans and $20 \%$ were properties. The majority, $55 \%$, of SAREB's share capital is private, with the remaining $45 \%$ owned by the Fund for Orderly Bank Restructuring (FOBR), or the Fondo de Reestructuración Ordenada Bancaria (FROB), the public entity created to manage the banking sector's restructuring process.
} 
a leverage ratio. In the case of an unsustainable demand-driven real estate boom, selecting instruments that primarily target bank borrowers (such as LTV ratio limits), is likely to be more effective and less costly than bank-oriented measures (such as higher capital requirements on mortgages with minimum risk weights or loss given default floors). The legal requirements are another important consideration in selecting the appropriate macroprudential instrument. Whereas some instruments are implemented under national laws, others depend on European laws, with legal requirements for some measures being more demanding than for others. The LTV ratio limit depends on national laws and is by far easier to implement than, e.g., the global systemically important institutions buffer, which depends on European legislation and requires notification to the European Commission, the ESRB, and the EBA. Finally, in selecting instruments, macroprudential authorities should favor instruments for which the purpose and design can be easily communicated and explained. The communication policy is an important and integral part of the macroprudential implementation. The LTV ratio limit was determined to be an easier policy to communicate, even to more general audiences, than other policies. For the preceding reasons, the LTV ratio limit appears to be an interesting and worthwhile macroprudential policy measure to study, especially in a model calibrated for Spain, which has significant issues in its real estate sector, as discussed above. ${ }^{22}$

Before the crisis, some measures were introduced by the Bank of Spain to alleviate the credit boom. In particular, Spain introduced dynamic provisioning, which was unrelated to specific bank loan losses, in 2000, with subsequent modifications to the formula parameters made in 2005 and 2008 . It has been found that provisioning has only a small impact on credit growth, whereas it is useful in building up countercyclical buffers to strengthen the solvency of banks. ${ }^{23}$ Although these measures seemed to be effective as preventive tools, in this case, they were not sufficient for Spain to avoid the crisis. BBVA (2012) points out that the Spanish dynamic provisioning was criticized on several grounds. First, international accounting bodies argued that it implied profit smoothing along the cycle and masked the real situation of the banks. Second, Spanish financial institutions complained about being subject to higher provisioning requirements than their competitors and, therefore, being put at a disadvantage in the single European market for financial services. The IMF (2011) finds that the instrument was

\footnotetext{
${ }^{22}$ For a deeper analysis, see ESRB (2015).

${ }^{23}$ Saurina (2009) argues that there was no guarantee, given the depth of the Spanish crisis at that time, that the amounts provisioned would be enough to cover the loan losses that banks were facing. Nevertheless, Saurina (2009) considers that dynamic provisions contributed to the stability of the Spanish financial system and allowed Spanish banks to deal with the crisis from a much better starting point. Similarly, Jiménez et al. (2012) find that countercyclical dynamic provisioning smoothed the cycle in the supply of credit and, in bad times, upheld firm financing and performance.
} 
effective in helping to cover rising credit losses during the crisis, but that the coverage was incomplete because of the severity of the actual losses. Furthermore, even though Spain was a pioneer in the use of macroprudential policies before the crisis, it is taking longer than the rest of the Euro area to implement them after the crisis.

Given the experience of the Spanish economy with dynamic provisioning, it seems sensible to examine alternative measures to enhance financial stability, including the LTV ratio rule. ESRB (2014b) considers that LTV ratio policies are effective in managing the credit cycle and improving banks' resilience.

Furthermore, from an empirical point of view, Cerutti et al. (2016) find that LTV ratio policies are especially effective in reducing systemic risk and they are more useful in the boom phases of the cycle than in the bust ones. Therefore, we consider that focusing on the LTV ratio in our paper is an appropriate means of studying the implications of the lack of coordination in implementing a macroprudential instrument.

\section{$3 \quad$ Model Setup}

We consider an infinite-horizon, two-country, two-sector economy inside a monetary union. The home country (Spain) is denoted by SP in the model equations and the other country, encompassing the rest of the union, is denoted by EUR. Households consume, work, and demand real estate. There is a financial intermediary in each country that provides mortgages and accepts deposits from consumers. Each country produces one differentiated intermediate good, but households consume goods from both countries. For simplicity, housing is a nontraded good and we assume that labor is immobile across the countries. Firms face a standard Calvo problem. In this economy, both final and intermediate goods are produced. Prices are sticky in the intermediate goods sector. A construction sector produces houses. Monetary policy is conducted by a single central bank that responds to a weighted average of inflation in both countries. There is a rule for the LTV ratio, which serves as a macroprudential measure. We allow for housing-market heterogeneity across the countries, so that we can pick up the specific features of each country.

\subsection{The Consumer's Problem}

There are three types of consumers in each country: unconstrained consumers, constrained consumers who borrow at a variable rate, and constrained consumers who borrow at a fixed rate. The proportion of 
each type of borrower is fixed and exogenous. ${ }^{24}$ Consumers can be constrained or unconstrained in the sense that constrained individuals need to collateralize their debt repayments in order to borrow from the financial intermediary, whereas unconstrained consumers do not. Interest payments in the next period cannot exceed a proportion of the future value of the current housing stock. In this way, the financial intermediary ensures that borrowers will be able to fulfill their debt obligations in the next period. As in Iacoviello (2005), we assume that constrained consumers are more impatient than unconstrained ones. ${ }^{25}$ There is a financial intermediary in each country. The financial intermediary in SP accepts deposits from domestic savers and it extends both fixed- and variable-rate loans to domestic borrowers.

\subsubsection{Unconstrained Consumers (Savers)}

Unconstrained consumers in SP maximize as follows:

$$
\max E_{0} \sum_{t=0}^{\infty} \beta^{t}\left(\ln C_{t}^{u}+j_{t} \ln H_{t}^{u}-\frac{\left(L_{t}^{u}\right)^{\eta}}{\eta}\right)
$$

Here, $E_{0}$ is the expectation operator, $\beta \in(0,1)$ is the discount factor, and $C_{t}^{u}, H_{t}^{u}$ and $L_{t}^{u}$ are consumption at $t$, the housing stock and hours worked, respectively. ${ }^{26} j_{t}$ represents the weight of housing in the utility function. We assume that $\log \left(j_{t}\right)=\log \left(j_{S P}\right)+u_{J t}$, where $u_{J t}$ follows an autoregressive process, where $j_{S P}$ is the steady-state value of the weight of housing. A shock to $j_{t}$ represents a shock to the marginal utility of housing. These shocks directly affect housing demand and, therefore, can be interpreted as a proxy for exogenous disturbances to house prices or, in other words, as a house price shock. $1 /(\eta-1)$ is the aggregate labor-supply elasticity.

Consumption consists of a bundle of domestically and foreign-produced goods, defined as: $C_{t}^{u}=$ $\left(C_{S P t}^{u}\right)^{n}\left(C_{E U R t}^{u}\right)^{1-n}$, where $n$ is the size of SP. Unconstrained consumers provide labor to both the consumption and the construction sectors, so that $L_{t}^{u}=\left[\left(L_{c t}^{u}\right)^{1-\nu}+\left(L_{h t}^{u}\right)^{1-\nu}\right]^{\frac{1}{1-\nu}}$.

The budget constraint for SP is as follows:

\footnotetext{
${ }^{24}$ We follow Rubio (2011) in leaving this proportion fixed and exogenous. According to the European Mortgage Federation, the different types of mortgage contracts offered across countries are largely a response to institutional or cultural factors, which are out of the scope of the present model. In the short run, the proportion of each type of mortgage contract can fluctuate, but typically it does not imply a change in the fixed- or variable-rate proportion at the country level.

${ }^{25}$ This assumption ensures that the borrowing constraint is binding in the steady state and that the economy is endogenously split into borrowers and savers.

${ }^{26} \mathrm{It}$ is assumed that housing services are proportional to the housing stock.
} 


$$
\begin{gathered}
P_{S P t} C_{S P t}^{u}+P_{E U R t} C_{E U R t}^{u}+Q_{S P t} H_{t}^{u}+R_{S P t-1} B_{t-1}^{u}+R_{t-1} D_{t-1}+\frac{\psi}{2} D_{t}^{2} \leq Q_{S P t} H_{t-1}^{u}+ \\
W_{c t}^{u} L_{c t}^{u}+W_{h t}^{u} L_{h t}^{u}+B_{t}^{u}+D_{t}+P_{S P t} F_{t}+P_{S P t} S_{t}
\end{gathered}
$$

where $P_{S P t}$ and $P_{E U R t}$ are the prices of the goods produced in countries SP and EUR, respectively, $Q_{S P t}$ is the housing price in SP, and $W_{c t}^{u}$ and $W_{h t}^{u}$ are the consumption and housing sector wages for unconstrained consumers. $B_{t}^{u}$ represents domestic bonds denominated in the common currency. $R_{S P t}$ is the nominal interest rate in SP. Positive bond holdings signify borrowing and negative bond holdings signify savings. However, as we will see, this group will choose not to borrow at all: they are the savers in this economy. $D_{t}$ are foreign-bond holdings by savers in $\mathrm{SP}^{27} R_{t}$ is the nominal rate of foreign bonds, which are denominated in euros. As is common in the literature, to ensure stationarity of net foreign assets, we introduce a small quadratic cost of deviating from zero foreign borrowing, $\frac{\psi}{2} D_{t}^{2} \cdot{ }^{28}$ Savers obtain interest on their savings. $S_{t}$ and $F_{t}$ are lump-sum profits received from the firms and the financial intermediary in SP, respectively.

Dividing by $P_{S P t}$, we can rewrite the budget constraint in terms of goods in SP:

$C_{S P t}^{u}+\frac{P_{E U R t}}{P_{S P t}} C_{E U R t}^{u}+q_{S P t} H_{t}^{u}+\frac{R_{S P t-1} b_{t-1}^{u}}{\pi_{S P t}}+\frac{R_{t-1} d_{t-1}}{P_{S P t}}+\frac{\psi}{2} d_{t}^{2} \leq q_{S P t} H_{t-1}^{u}+w_{c t}^{u} L_{c t}^{u}+w_{h t}^{u} L_{h t}^{u}+b_{t}^{u}+d_{t}+F_{t}+S_{t}$,

where $\pi_{S P t}$ denotes inflation for the goods produced in SP, defined as $P_{S P t} / P_{S P t-1} . q_{S P t}$ is the house price in SP, defined in terms of the price of goods in SP.

Maximizing (1) subject to (3), we obtain the first-order conditions for the unconstrained group:

$$
\begin{gathered}
\frac{C_{S P t}^{u}}{C_{E U R t}^{u}}=\frac{n P_{E U R t}}{(1-n) P_{S P t}}, \\
\frac{1}{C_{S P t}^{u}}=\beta E_{t}\left(\frac{R_{S P t}}{\pi_{S P t+1} C_{S P t+1}^{u}}\right),
\end{gathered}
$$

\footnotetext{
${ }^{27}$ Savers have access to international financial markets.

${ }^{28}$ See Iacoviello and Smets (2006) for a similar specification of the budget constraint.
} 


$$
\begin{gathered}
\frac{1-\psi d_{t}}{C_{S P t}^{u}}=\beta E_{t}\left(\frac{R_{t}}{\pi_{S P t+1} C_{S P t+1}^{u}}\right), \\
w_{c t}^{u}=\left(L_{t}^{u}\right)^{\eta-1}\left(L_{c t}^{u}\right)^{-\nu}\left[\left(L_{c t}^{u}\right)^{1-\nu}+\left(L_{h t}^{u}\right)^{1-\nu}\right]^{\frac{\nu}{1-\nu}} \frac{C_{S P t}^{u}}{n}, \\
w_{h t}^{u}=\left(L_{t}^{u}\right)^{\eta-1}\left(L_{h t}^{u}\right)^{-\nu}\left[\left(L_{c t}^{u}\right)^{1-\nu}+\left(L_{h t}^{u}\right)^{1-\nu}\right]^{\frac{\nu}{1-\nu}} \frac{C_{S P t}^{u}}{n}, \\
\frac{j_{t}}{H_{t}^{u}}=\frac{n}{C_{S P t}^{u}} q_{S P t}-\beta E_{t} \frac{n}{C_{S P t+1}^{u}} q_{S P t+1} .
\end{gathered}
$$

Equation (4) equates the marginal rate of substitution between goods to the relative price. Equation (5) is the Euler equation for consumption. Equation (6) is the first-order condition for net foreign assets. Equations (7) and (8) are the labor-supply conditions for both sectors. These equations are standard. Equation (9) is the Euler equation for housing, which states that, at the margin, the benefits from consuming housing have to be equal to the costs.

Combining (5) and (6), we obtain a nonarbitrage condition between home and foreign bonds: ${ }^{29}$

$$
R_{S P t}=\frac{R_{t}}{\left(1-\psi d_{t}\right)}
$$

As all consumption goods are traded and there are no barriers to trade, we assume, in this paper, that the law of one price holds:

$$
P_{S P t}=P_{S P t}^{*},
$$

where variables with a star denote foreign variables.

\subsubsection{Constrained Consumers (Borrowers)}

There are two types of constrained consumers in SP: those who borrow at a variable rate and those who do so at a fixed rate. The difference between the two groups is the interest rate they are charged. The variable-rate constrained consumer faces $R_{S P t}$, which will coincide with the rate set by the central bank.

\footnotetext{
${ }^{29}$ The log-linearized version of this equation could be interpreted as the uncovered interest-rate parity.
} 
The fixed-rate borrower pays $\bar{R}_{S P t}$, derived from the financial intermediary's problem. The proportion of variable-rate consumers in $\mathrm{SP}$ is constant and exogenous and is equal to $\alpha_{S P} \in[0,1]$.

Constrained consumers are more impatient than unconstrained ones, i.e., $\widetilde{\beta}<\beta$. Constrained consumers face a collateral constraint: the expected debt repayment in the next period cannot exceed a proportion of tomorrow's expected value of today's housing stock:

$$
\begin{aligned}
& E_{t} \frac{R_{S P t}}{\pi_{S P t+1}} b_{t}^{c v} \leq k_{S P t} E_{t} q_{S P t+1} H_{t}^{c v}, \\
& E_{t} \frac{\bar{R}_{S P t}}{\pi_{S P t+1}} b_{t}^{c f} \leq k_{S P t} E_{t} q_{S P t+1} H_{t}^{c f},
\end{aligned}
$$

where equations (12) and (13) represent the collateral constraint for the variable- and fixed-rate borrowers, respectively. $k_{S P t}$ can be interpreted as the LTV ratio in SP. Note that in models with collateral constraints, the LTV ratio is typically considered to be exogenous. At the macroeconomic level, LTV ratios depend partly on exogenous factors, including regulation. This parameter is usually calibrated to match the average LTV ratio in the country analyzed. However, in this model, it can vary, depending on economic conditions, because it is utilized as a macroprudential policy variable. As we will see, when we introduce the problem of the financial intermediary, $\bar{R}_{S P t}$ is an aggregate interest rate that contains information on all the past fixed-interest rates associated with past debt. In each period, this aggregate interest rate is updated with a new interest rate, linked to the new amount of debt originating in that period.

Without loss of generality, we present the problem only for the variable-rate borrower because the problem for the fixed-rate borrower is symmetrical. Variable-rate borrowers maximize their lifetime utility function as follows:

$$
\max E_{0} \sum_{t=0}^{\infty} \widetilde{\beta}^{t}\left(\ln C_{t}^{c v}+j_{t} \ln H_{t}^{c v}-\frac{\left(L_{t}^{c v}\right)^{\eta}}{\eta}\right)
$$

where $C_{t}^{c v}=\left(C_{S P t}^{c v}\right)^{n}\left(C_{E U R t}^{c v}\right)^{1-n}, L_{t}^{c v}=\left[\left(L_{c t}^{c v}\right)^{1-\nu}+\left(L_{h t}^{c v}\right)^{1-\nu}\right]^{\frac{1}{1-\nu}}$, subject to the budget constraint (in terms of goods in $\mathrm{SP}$ ):

$$
C_{S P t}^{c v}+\frac{P_{E U R t}}{P_{S P t}} C_{E U R t}^{c v}+q_{S P t} H_{t}^{c v}+\frac{R_{S P t-1} b_{t-1}^{c v}}{\pi_{S P t}} \leq q_{S P t} H_{t-1}^{c v}+w_{c t}^{c v} L_{c t}^{c v}+w_{h t}^{c v} L_{c t}^{c v}+b_{t}^{c v}
$$


and subject to the collateral constraint (12). Note that variable-rate borrowers repay all debt every period and acquire new debt at the current new interest rate. This assumption implies that the interest rate on variable-rate mortgages is revised every period for the whole debt stock and changed according to the policy rate. ${ }^{30}$ To make the problem for fixed-rate borrowers symmetrical and analogous to existing models with borrowing constraints, we assume the same debt-repayment structure for this type of borrower. Obviously, fixed-rate contracts are not revised every period. However, to make the model more realistic, but still tractable, the fixed-interest rate will be such that a revised fixed rate will be applied only on new debt, keeping the interest rate applied to existing debt constant. In this way, we reconcile the structure of the model with the fact that fixed-rate contracts are long term. ${ }^{31}$

The first-order conditions for the consumers are as follows:

$$
\begin{aligned}
& \frac{C_{S P t}^{c v}}{C_{E U R t}^{c v}}=\frac{n P_{E U R t}}{(1-n) P_{S P t}} \\
& \frac{n}{C_{S P t}^{c v}}=\widetilde{\beta} E_{t}\left(\frac{n R_{S P t}}{\pi_{S P t+1} C_{S P t+1}^{c v}}\right)+\lambda_{t}^{c v} R_{S P t}, \\
& w_{c t}^{c v}=\left(L_{t}^{c v}\right)^{\eta-1}\left(L_{c t}^{c v}\right)^{-\nu}\left[\left(L_{c t}^{c v}\right)^{1-\nu}+\left(L_{h t}^{c v}\right)^{1-\nu}\right]^{\frac{\nu}{1-\nu}} \frac{C_{S P t}^{c v}}{n}, \\
& w_{h t}^{c v}=\left(L_{t}^{c v}\right)^{\eta-1}\left(L_{h t}^{c v}\right)^{-\nu}\left[\left(L_{c t}^{c v}\right)^{1-\nu}+\left(L_{h t}^{c v}\right)^{1-\nu}\right]^{\frac{\nu}{1-\nu}} \frac{C_{S P t}^{c v}}{n}, \\
& \frac{j_{t}}{H_{t}^{c v}}=\frac{n}{C_{S P t}^{c v}} q_{S P t}-\widetilde{\beta} E_{t} \frac{n}{C_{S P t+1}^{c v}} q_{S P t+1}-\lambda_{t}^{c v} k_{S P t} E_{t} q_{S P t+1} \pi_{S P t+1} .
\end{aligned}
$$

These first-order conditions differ from those for the unconstrained individuals. In the case of constrained consumers, the Lagrange multiplier on the borrowing constraint $\left(\lambda_{t}^{c v}\right)$ appears in equations (17) and (20). As in Iacoviello (2005), the borrowing constraint is always binding, so that constrained individuals borrow the maximum amount that they are allowed to borrow and their saving is zero. ${ }^{32}$

\footnotetext{
${ }^{30}$ This assumption is consistent with reality as variable interest rates are revised very frequently and change according to an interest-rate index that is tied to the interest rate set by the central bank.

${ }^{31}$ Another option would be to have an overlapping generations model in which we are able to keep track of the debt issued each period. However, the model would become more complex and less comparable with the standard collateral constraint DSGE models, such as that of Iacoviello (2005).

${ }^{32}$ From the Euler equations for consumption for the unconstrained consumers, we know that $R_{S P}=1 / \beta$, where variables without a time subscript denote steady-state variables. If we combine this result with the Euler equation for consumption for the constrained individual, we have $\lambda^{c v}=n(\beta-\widetilde{\beta}) / C_{S P}^{c v}>0$. Given that $\beta>\widetilde{\beta}$, the borrowing constraint holds with
} 
The problem for consumers in EUR is analogous to that for consumers in SP.

\subsection{The Financial Intermediary}

We assume a competitive framework and, thus, the intermediary takes the variable interest rate as given. $^{33}$ The profits of the financial intermediary are defined as follows: ${ }^{34}$

$$
F_{t}=\alpha_{S P} R_{S P t-1} b_{t-1}^{c v}+\left(1-\alpha_{S P}\right) \bar{R}_{S P t-1} b_{t-1}^{c f}-R_{S P t-1} b_{t-1}^{u},
$$

where $F_{t}$ are the profits of the financial intermediary. $R_{S P t}$ and $\bar{R}_{S P t}$ are the variable and the fixed rate, respectively.

In equilibrium, aggregate borrowing and saving must be equal, i.e.:

$$
\alpha_{S P} b_{t}^{c v}+\left(1-\alpha_{S P}\right) b_{t}^{c f}=b_{t}^{u}
$$

Substituting (22) into (21), we obtain:

$$
F_{t}=\left(1-\alpha_{S P}\right) b_{t-1}^{c f}\left(\bar{R}_{S P t-1}-R_{S P t-1}\right)
$$

For the two types of mortgage to be offered, the fixed-interest rate has to be such that the intermediary is indifferent between lending at a variable or fixed rate. Hence, the expected discounted profits that the intermediary obtains by lending new debt in a given period at a fixed-interest rate must be equal to the expected discounted profits that the intermediary would obtain by lending at a variable rate:

$$
E_{\tau} \sum_{i=\tau+1}^{\infty} \beta^{i-\tau} \Lambda_{\tau, i}{\overline{R_{S P}}}^{O P T}=E_{\tau} \sum_{i=\tau+1}^{\infty} \beta^{i-\tau} \Lambda_{\tau, i} R_{S P t-1}
$$

where $\Lambda_{t, i}=\frac{C_{S P t}^{u}}{C_{S P t+i}^{u}}$ is the relevant discount factor for the unconstrained consumer. As the financial intermediary is owned by the savers, their stochastic discount factor is applied to the financial intermediary's problem. Note that, as stated previously, the variable-rate debt applies to one period, but the portion of new debt acquired at a fixed rate is associated with a long-term contract. As the agent is equality in the steady state. As the model is log-linearized around the steady state and low uncertainty is assumed, this result can be generalized to off-steady-state dynamics.

${ }^{33}$ See Andrés et al. (2013) for a housing model with collateral constraints in which banks are imperfectly competitive and are able to set optimal lending rates.

${ }^{34}$ The superscript $c v$ signifies "constrained variable" and $c f$ signifies "constrained fixed." 
infinitely lived, we assume here that the maturity of fixed-rate mortgages is also infinity. We can obtain the equilibrium value of the fixed rate in period $\tau$ from expression (24) :

$$
\bar{R}_{S P \tau}^{O P T}=\frac{E_{\tau} \sum_{i=\tau+1}^{\infty} \beta^{i-\tau} \Lambda_{\tau, i} R_{S P t-1}}{E_{\tau} \sum_{i=\tau+1}^{\infty} \beta^{i-\tau} \Lambda_{\tau, i}} .
$$

Equation (25) states that, for every new debt issued at date $\tau$, there is a different fixed-interest rate that has to be equal to a discounted average of future variable-interest rates. Note that this is not a condition on the debt stock, but on the new amount of debt obtained in a given period. New debt at a given point in time is associated with a different fixed-interest rate than that applied to the debt stock. Both the fixed-interest rate in period $\tau$ and the new amount of debt in period $\tau$ are fixed for all future periods. However, the fixed-interest rate varies depending on the date that the debt was issued so that, in every period, there is a new fixed-interest rate associated with new debt in this period. If we consider fixed-rate loans to be long term, the financial intermediary obtains interest payments every period from the whole debt stock, not only from the new debt. Hence, we can define an aggregate fixed-interest rate as the one that the financial intermediary effectively charges every period for the whole mortgages stock. This aggregate fixed-interest rate is composed of all past fixed-interest rates and past debt, together with the current-period equilibrium fixed-interest rate and the new amount of debt. Therefore, the effective fixed-interest rate that the financial intermediary charges for the fixed-rate debt stock every period is as follows:

$$
\bar{R}_{S P t}=\left\{\begin{array}{c}
\frac{\bar{R}_{S P t-1} b_{t-1}^{c f}+\bar{R}_{S P t}^{O P T}\left(b_{t}^{c f}-b_{t-1}^{c f}\right)}{b_{t}^{c f}} \text { if } b_{t}^{c f}>b_{t-1}^{c f} \\
\bar{R}_{S P t-1} \text { if } b_{t}^{c f} \leq b_{t-1}^{c f}
\end{array}\right\} .
$$

Equation (26) states that the fixed-interest rate that the financial intermediary charges today is an average of what it charged in the previous period for the previous mortgages stock and what it charges in the current period for the new amount. If there is no new debt, the fixed-interest rate will be equal to that of the previous period. Then, in the same way that variable rates are revised every period, fixed rates are revised by including the new optimal fixed-interest rate for the new debt originating in this period. Importantly, this assumption is not crucial for our results. Both $\bar{R}_{S P \tau}^{O P T}$ and $\bar{R}_{S P t}$ are practically unaffected by interest rate shocks. ${ }^{35}$ This assumption is a way to make the model compatible with the

\footnotetext{
${ }^{35}$ In log-linearized terms, the new fixed interest rate is always equal to the past fixed interest rate and, therefore, equation (26) does not introduce a kink.
} 
fact that fixed-rate loans are not one-period assets but longer-term ones.

As noted above, any profits from financial intermediation are rebated to the unconstrained consumers every period. The financial intermediary is competitive and does not make profits in the absence of shocks but, should a shock occur, the fact that only the variable-interest rate is directly affected can generate nonzero profits. ${ }^{36}$

The financial intermediary problem for EUR is symmetrical.

\subsection{Firms}

\subsubsection{Final-Consumption Goods Producers}

In SP, there is a continuum of final-goods producers that aggregate intermediate goods according to the production function:

$$
Y_{S P t}^{k}=\left[\int_{0}^{1} Y_{S P t}^{k}(z)^{\frac{\varepsilon-1}{\varepsilon}} d z\right]^{\frac{\varepsilon}{\varepsilon-1}}
$$

where $\varepsilon>1$ is the elasticity of substitution among intermediate goods.

The total demand for intermediate good $z$ is given by $Y_{S P t}(z)=\left(\frac{P_{S P}(z)}{P_{S P t}}\right)^{-\varepsilon} Y_{S P t}$, and the price index is $P_{S P t}=\left[\int_{0}^{1} P_{S P t}(z)^{1-\varepsilon} d z\right]^{\frac{1}{\varepsilon-1}}$.

\subsubsection{Intermediate Goods and House Producers}

The intermediate-goods consumption market is monopolistically competitive. Following Iacoviello (2005), intermediate goods are produced according to the following production function:

$$
Y_{S P t}(z)=\xi_{t}\left(L_{c t}^{u}(z)\right)^{\gamma}\left(L_{c t}^{c}(z)\right)^{(1-\gamma)},
$$

where $\xi_{t}$ represents technology. We assume that $\log \xi_{t}=\rho_{\xi} \log \xi_{t-1}+u_{\xi t}$, where $\rho_{\xi}$ is the autoregressive coefficient and $u_{\xi t}$ is a normally distributed shock to technology. $\gamma \in[0,1]$ measures the relative size of each group in terms of labor. $L_{t}^{c}$ is labor supplied by constrained consumers, defined as $\alpha_{S P} L_{t}^{c v}+$ $\left(1-\alpha_{S P}\right) L_{t}^{c f}$.

Symmetry across firms allows us to avoid index $z$ and to rewrite equation (28) as:

$$
Y_{S P t}=\xi_{t}\left(L_{c t}^{u}\right)^{\gamma}\left(L_{c t}^{c}\right)^{(1-\gamma)} .
$$

\footnotetext{
${ }^{36}$ This modeling of the fixed interest rate follows Rubio (2011) and Rubio (2014).
} 
The production function for housing investment is as follows:

$$
I_{S P t}=\xi_{t}\left(L_{h t}^{u}\right)^{\gamma}\left(L_{h t}^{c}\right)^{(1-\gamma)}
$$

Producers maximize profits as follows:

$$
\max _{L_{c t}, L_{h t}} \frac{Y_{S P t}}{X_{t}}+q_{t} I_{S P t}-w_{c t}^{u} L_{c t}^{u}-w_{h t}^{u} L_{h t}^{u}-w_{c t}^{c v} L_{c t}^{c v}-w_{h t}^{c v} L_{t}^{c v}-w_{c t}^{c f} L_{c t}^{c f}-w_{h t}^{c f} L_{t}^{c f}
$$

The first-order conditions for labor demand are as follows:

$$
\begin{gathered}
w_{c t}^{u}=\frac{1}{X_{t}} \gamma \frac{Y_{S P t}}{L_{c t}^{u}}, \\
w_{c t}^{c v}=w_{c t}^{c f}=\frac{1}{X_{t}}(1-\gamma) \frac{Y_{S P t}}{L_{c t}^{c}}, \\
w_{h t}^{u}=\gamma \frac{q_{t} I_{S P t}}{L_{h t}^{u}}, \\
w_{h t}^{c v}=w_{h t}^{c f}=(1-\gamma) \frac{q_{t} I_{S P t}}{L_{h t}^{c}},
\end{gathered}
$$

where $X_{t}$ is the markup, or the inverse of marginal cost. The price-setting problem for the intermediategoods producers is a standard Calvo-Yun case. An intermediate-goods producer sells goods at price $P_{S P t}(z)$ and $1-\theta$ is the probability of being able to change the sale price in every period. The optimal reset price $P_{S P t}^{O P T}(z)$ solves the following:

$$
\sum_{k=0}^{\infty}(\theta \beta)^{k} E_{t}\left\{\Lambda_{t, k}\left[\frac{P_{S P t}^{O P T}(z)}{P_{S P t+k}}-\frac{\varepsilon /(\varepsilon-1)}{X_{t+k}}\right] Y_{S P t+k}^{O P T}(z)\right\}=0 .
$$

The aggregate price level is given as follows:

$$
P_{S P t}=\left[\theta P_{S P t-1}^{1-\varepsilon}+(1-\theta)\left(P_{S P t}^{O P T}\right)^{1-\varepsilon}\right]^{1 /(1-\varepsilon)} .
$$

Using (36) and (37) and log-linearizing, we can obtain the standard forward-looking Phillips curve. ${ }^{37}$ The firm problem is similar for EUR.

\footnotetext{
${ }^{37}$ This Phillips curve is consistent with other two-country models with financial accelerators. See, e.g., Gilchrist et al. (2002) or Iacoviello and Smets (2006).
} 


\subsection{Aggregate Variables and Market Clearing}

Given $\alpha_{S P}$, the fraction of variable-rate borrowers in SP, we can define aggregates across constrained consumers as the sum of variable-rate and fixed-rate aggregates, so that $C_{t}^{c} \equiv \alpha_{S P} C_{t}^{c v}+\left(1-\alpha_{S P}\right) C_{t}^{c f}$, $H_{t}^{c} \equiv \alpha_{S P} H_{t}^{c v}+\left(1-\alpha_{S P}\right) H_{t}^{c f}$ and $b_{t}^{c} \equiv \alpha_{S P} b_{t}^{c v}+\left(1-\alpha_{S P}\right) b_{t}^{c f}$.

Therefore, economy-wide aggregates in country SP are $C_{t} \equiv C_{t}^{u}+C_{t}^{c}, L_{t} \equiv L_{t}^{u}+L_{t}^{c}$. Domestic housing market clearing requires that $I_{S P t} \equiv\left(H_{t}^{u}-H_{t-1}^{u}\right)+\left(H_{t}^{c}-H_{t-1}^{c}\right)$.

The market-clearing condition for the final good in country SP is $n Y_{S P t}=n C_{S P t}+(1-n) C_{S P t}^{*}+$ $n \frac{\psi}{2} d_{t}^{2}$. Domestic financial markets clear as follows: $b_{t}^{c}=b_{t}^{u}$. The world bond market-clearing condition is $n d_{t}+(1-n) \frac{P_{E U R t}}{P_{S P t}} d_{t}^{*}=0$, where $d_{t}$ denotes the foreign bonds in real terms. The net foreign asset position follows $d_{t}=\frac{R_{t-1}}{\left(1-\psi d_{t}\right) \pi_{S P t}} d_{t-1}+Y_{S P t}-C_{S P t}-\frac{P_{E U R t}}{P_{S P t}} C_{E U R t}$. Everything is similar in EUR.

\subsection{Monetary Policy}

The model is closed, with a Taylor rule and interest-rate smoothing, with interest rates set by a single central bank, ${ }^{38}$

$$
R_{t}=\left(R_{t-1}\right)^{\rho}\left(\left[\left(\pi_{S P t}\right)^{n}\left(\pi_{E U R t}\right)^{(1-n)}\right]^{\left(1+\phi_{\pi}\right)} R\right)^{1-\rho} \varepsilon_{R, t}
$$

$0 \leq \rho \leq 1$ is the parameter associated with interest-rate inertia. $\left(1+\phi_{\pi}\right)$ measures the sensitivity of interest rates to current inflation. $\varepsilon_{R, t}$ is a white noise shock process, with zero mean and variance $\sigma_{\varepsilon}^{2}$. This rule is consistent with the primary objective of the ECB being price stability.

\subsection{Macroprudential Policy}

As an approximation for a realistic macroprudential policy, we consider a Taylor-type rule for the LTV ratio. In standard models, the LTV ratio is a fixed parameter that is not affected by economic conditions. However, using regulations on LTV ratios can be considered as a way to moderate credit booms. When the LTV ratio is high, the collateral constraint is looser and borrowers will borrow as much as they are allowed to, given that the constraint is binding when tight. Lowering the LTV ratio tightens the constraint and restricts the loans that borrowers can obtain. As a result of recent research on macroprudential policies, Taylor-type rules for the LTV ratio have been proposed, which would ensure

\footnotetext{
${ }^{38}$ This type of rule is used in other monetary union models. See Iacoviello and Smets (2006) and Aspachs and Rabanal (2011). Furthermore, as shown in Iacoviello (2005) and Rubio and Carrasco-Gallego (2013), a rule that only responds to inflation enhances the financial accelerator.
} 
that the ratio reacts inversely to variables including GDP growth rates, credit, the credit-to-GDP ratio and house prices. These rules are a simple illustration of how a macroprudential policy could work in practice. Here, we assume that there exists a macroprudential Taylor-type rule for the LTV ratio that ensures that the ratio responds to deviations of credit from the steady state. In this way, we consider the macroprudential regulator's objective of moderating economic booms, which could lead to an excessive growth of credit. We consider a decentralized policy rule, so that each country can implement its own rule at a national level, responding to its own credit variables, as follows:

$$
\begin{gathered}
k_{S P t}=k_{S S_{-} S P}\left(\frac{b_{S P t}}{b_{S P}}\right)^{-\phi_{S P}^{b}}, \\
k_{E U R t}=k_{S S_{-} E U R}\left(\frac{b_{E U R t}}{b_{E U R}}\right)^{-\phi_{E U R}^{b}},
\end{gathered}
$$

where $k_{S S_{-} S P}$ and $k_{S S_{-} E U R}$ are the steady-state values for the LTV ratio in SP and the rest of the Euro area, respectively. $\phi_{S P}^{b} \geq 0$ and $\phi_{E U R}^{b} \geq 0$ measure the response of the LTV ratio to deviations of credit from its steady state in SP and the rest of the Euro area, respectively.

\subsection{Parameter Values}

Parameters are calibrated to reflect the economy of Spain and the economy of the rest of the Euro area. Some of the parameters are standard and common to both economies, whereas others are specifically calibrated for each economy. Tables A1 and A2 in the Appendix present a summary of the parameter values.

Discount factors are set to be common in both economies, following the standard values in the literature. The discount factor for savers, $\beta$, is set to 0.99 so that the annual interest rate is $4 \%$ in the steady state. The discount factor for borrowers, $\widetilde{\beta}$, is set to $0.98 .{ }^{39}$ The steady-state weight of housing in the utility function, $j$, is set to 0.12 and 0.143 for the Euro area and Spain, respectively. This parameter reflects the differences between Spain and the Euro area in terms of the ratio of housing wealth to GDP. ${ }^{40}$ We set $\eta=2$, implying that the labor supply elasticity has a value of $1 .{ }^{41}$ Following Horvath (2000) and

\footnotetext{
${ }^{39}$ Lawrence (1991) estimated discount factors for poor consumers at between 0.95 and 0.98 at quarterly frequency.

${ }^{40}$ Following Aspachs and Rabanal (2008), we consider 1.40, which is the ratio of housing wealth to GDP across most industrialized countries, to be a proxy for the Euro area. This delivers a parameter value of 0.12 for the steady-state weight of housing in the utility function. For Spain, we use the parameter calibrated in Ortega et al. (2011).

${ }^{41}$ Microeconomic estimates usually suggest values in a range from zero to 0.5 (for males). Domeij and Flodén (2006) show that, in the presence of borrowing constraints, this estimate could have a downward bias of $50 \%$.
} 
Iacoviello and Neri (2010), we set the inverse elasticity of substitution across hours in the two sectors to one. For the LTV ratio, we use steady-state values of 0.79 and 0.725 for the Euro area and Spain, respectively, based on the LTV ratio observed in the data. ${ }^{42}$ The labor-income share of unconstrained consumers, $\gamma$, is set to $0.7 .{ }^{43}$ We pick a value of 6 for $\varepsilon$, the elasticity of substitution among intermediate goods. This value implies a steady-state markup of 1.2. The probability of not changing prices, $\theta$, is set to 0.75 , implying that prices change every four quarters on average. For the Taylor-rule parameters, we use $\rho=0.8$ and $\phi_{\pi}=0.5$. The first value reflects a realistic degree of interest-rate smoothing. ${ }^{44} \phi_{\pi}$ is consistent with the original parameters proposed by Taylor in 1993. We consider $\alpha$, the proportion of variable-rate mortgages, to be 0.43 and 0.91 in the Euro area and Spain, respectively. ${ }^{45}$ The size of Spain is considered to be $10 \%$ of the size of the Euro area. ${ }^{46}$ A technology shock involves $1 \%$ positive technology with 0.9 persistence. ${ }^{47}$ Housing demand shocks have a 0.95 persistence. $^{48}$ We set the size of the shock to the housing-demand parameter at $24.89 \%$, consistent with Iacoviello (2005). Monetary policy shocks are represented by a $0.29 \%$ increase in the interest rate on a quarterly basis, as in Iacoviello (2005).

\section{Optimal Macroprudential Policy}

In this section, we determine the optimal macroprudential policy that maximizes country welfare. We consider two cases: one that corresponds to the current situation, where Spain is not implementing macroprudential policies yet but the rest of the Euro area is; and a second case in which Spain implements macroprudential policies along with the rest of the Euro area.

The following subsection describes our welfare measure.

\footnotetext{
${ }^{42}$ This value corresponds to the typical LTV ratio for a first-time house buyer. See ECB (2009), Table 2.

${ }^{43}$ This value is within the range of estimates provided by Iacoviello (2005) and Iacoviello and Neri (2010) for the US, and those of Campbell and Mankiw (1991) for the US, Canada, France, and Sweden. Therefore, we consider it to be valid for most countries in the Euro area.

${ }^{44}$ See McCallum (2001).

${ }^{45}$ The data are from ECB (2009), Housing Finance in the Euro area (Table 2). Loans with variable interest rates are loans extended at floating rates or with an initial period of fixed rates of up to one year. If the fixed interest rate period is longer than one year, the housing loan is considered to be a fixed rate loan.

${ }^{46}$ We follow Andrés et al. (2013) in choosing this value.

${ }^{47}$ This high persistence value for technology shocks is consistent with what is commonly reported in the literature. Smets and Wouters (2003) estimate a value of 0.822 for this parameter in Europe and Iacoviello and Neri (2010) estimate a value of 0.93 for the US.

${ }^{48}$ The persistence of the housing demand shock is consistent with the estimates in Iacoviello and Neri (2010).
} 


\subsection{Welfare Measure}

To provide a welfare measure, we numerically evaluate how cross-country asymmetries affect welfare for a given policy rule and for technology shocks. As discussed in Benigno and Woodford (2012), the two approaches that have recently been used for welfare analysis in DSGE models are either to characterize the optimal Ramsey policy, or to solve the model using a second-order approximation of the structural equations for the given policy and to then evaluate welfare using this solution. As in Mendicino and Pescatori (2007), we take the latter approach so that we can evaluate the welfare of the two types of agents separately. ${ }^{49}$ The individual welfare for savers and borrowers, respectively, in SP is defined as follows:

$$
\begin{aligned}
V_{u, t} & \equiv E_{t} \sum_{m=0}^{\infty} \beta^{m}\left(\ln C_{t+m}^{u}+j_{t} \ln H_{t+m}^{u}-\frac{\left(L_{t+m}^{u}\right)^{\eta}}{\eta}\right), \\
V_{c v, t} & \equiv E_{t} \sum_{m=0}^{\infty} \widetilde{\beta}^{m}\left(\ln C_{t+m}^{c v}+j_{t} \ln H_{t+m}^{c v}-\frac{\left(L_{t+m}^{c v}\right)^{\eta}}{\eta}\right),
\end{aligned}
$$

Following Mendicino and Pescatori (2007), we define social welfare in SP as a weighted sum of the individual welfare for the different types of households:

$$
V_{t}=(1-\beta) V_{u, t}+(1-\widetilde{\beta})\left[\alpha_{A} V_{c v, t}+\left(1-\alpha_{A}\right) V_{c f, t}\right]
$$

The welfare of borrowers and savers is weighted by $(1-\widetilde{\beta})$ and $(1-\beta)$, respectively, so that the two groups receive the same level of utility from a constant consumption stream. For EUR, everything is symmetrical to SP.

Total welfare is defined as a weighted sum of the welfare in the two countries:

$$
W_{t}=n V_{t}+(1-n) V_{t}^{*}
$$

\subsection{Optimal Parameters}

Table 1 presents the optimized parameters for the macroprudential rules, in particular for those described in equations (39) and (40). We take monetary policy as given and determine the parameters that

\footnotetext{
${ }^{49}$ We use Dynare software to obtain a solution for the equilibrium implied by a given policy by solving a second-order approximation of the constraints. We then evaluate welfare under the policy using this approximate solution, as in SchmittGrohe and Uribe (2004). See Monacelli (2006) for an example of the Ramsey approach in a model with heterogeneous consumers.
} 
maximize welfare for the two cases mentioned above, i.e.:

1. Spain does not implement macroprudential policies but the rest of the Euro area (EUR) does, i.e., the no-coordination case.

2. Spain implements macroprudential policies as well as the Euro area (SP and EUR), i.e., the coordination case.

\begin{tabular}{ccc}
\hline \hline \multicolumn{2}{c}{ Table 1: } & Optimal Macroprudential Policy \\
\hline \hline & EUR & SP and EUR \\
$\phi_{S P}^{b *}$ & - & 0.99 \\
$\phi_{E U R}^{b *}$ & 1.9 & 1.9 \\
\hline \hline
\end{tabular}

The first column of Table 1 corresponds to the case in which Spain is not implementing macroprudential policies but the rest of the union is and, thus, the countries are not coordinated in their policies. In this column, we find the optimal parameter for the reaction of the LTV ratio to deviations of credit from its steady state only for the rest of the Euro area. In the second column, we find the optimal parameter for both Spain and the rest of the union. We see that the optimal policy for Spain is less aggressive than that for the rest of the Euro area. The reason for this relates to the mortgage interest rate that each region faces. In Spain, mortgage rates are variable and monetary policy is more effective. In the rest of the Euro area, mortgage rates are fixed and the macroprudential policy needs to be more aggressive to compensate for the less-effective monetary policy.

\begin{tabular}{ccc}
\hline \hline \multicolumn{3}{c}{ Table 2: Welfare Gain } \\
\hline \hline SP & $\mathbf{0 . 0 4}$ & $\mathbf{0 . 5 9}$ \\
Borrowers & 0.17 & 1.53 \\
Savers & -0.11 & -0.36 \\
\hline \hline EUR & $\mathbf{9 . 4 4}$ & $\mathbf{9 . 9 2}$ \\
Borrowers & 31.5 & 33.14 \\
Savers & -0.67 & -0.68 \\
\hline \hline Union & $\mathbf{7 . 2 9}$ & $\mathbf{8 . 0 1}$ \\
\hline \hline
\end{tabular}

Then, in Table 2, using the optimal parameters described above, we present the welfare gains (in consumption equivalents) resulting from implementing this optimal rule. As in Ascari and Ropele (2012), 
we find the constant fraction of steady-state consumption that would have to be transferred to the agent if a welfare loss occurred under the new parameterization. ${ }^{50}$ Here, a positive value for consumption units represents a welfare increase; i.e., it indicates how much the agent would pay in units of consumption to be better off. A negative value means that welfare has decreased, i.e., it indicates by how much an agent should be compensated in units of consumption for the welfare loss. As a benchmark, we take the case in which there are no macroprudential policies in place.

We can observe from Table 2 that macroprudential policies are welfare enhancing. ${ }^{51}$ Even if only the rest of the Euro area has an LTV ratio rule, and Spain does not coordinate (the first column of Table 2), this is welfare improving for the whole union, including Spain. However, the gain is even larger if Spain also implements the policies, i.e., if there is coordination (the second column of Table 2).

In models with collateral constraints, macroprudential policies deliver welfare gains because of the negative distortion arising from the constraint. That is, in these kinds of models, the collateral constraint is always binding and, therefore, borrowers are not able to smooth consumption as savers do. Thus, a policy that enhances financial stability results in a more stable scenario for borrowers, with a more stable consumption path and helps reducing the negative effects of the constraint. However, as is usual for this kind of model, a trade-off occurs between borrowers and savers. Savers are worse off with macroprudential policies because the macroprudential policy goals may conflict with monetary policy goals, namely price stability. Note that, in this model, the sticky-price assumption creates a distortion that affects savers. As the savers are the owners of the firms, ideally they would prefer a world in which there is price stability, which is the goal of monetary policy. If monetary policy loses effectiveness when macroprudential policies are introduced, savers may not like the latter policies. In the aggregate, the economy benefits from macroprudential policies but the gain comes from the borrowers' side.

\footnotetext{
${ }^{50}$ The consumption equivalent measure for the saver, as in Ascari and Ropele (2009), is given by $1-\exp \left[(1-\beta)\left(V_{u, n e w}-\right.\right.$ $\left.V_{u, o l d}\right]$, and analogously for the other agents.

${ }^{51}$ Note that these values may seem larger than those found for standard models. However, we have to consider the fact that the collateral constraint makes borrowers' welfare very sensitive to changes in macroprudential policies. Furthermore, we are not optimizing monetary policy and, therefore, introducing an optimal policy delivers large welfare gains.
} 


\section{Table 3: Volatilities}

\begin{tabular}{cccc}
\hline \hline & No Macropru & EUR & SP and EUR \\
\hline SP & & & \\
$\sigma_{y}$ & 2.0107 & 1.9745 & 1.9784 \\
$\sigma_{\pi}$ & 0.2228 & 0.2351 & 0.2389 \\
$\sigma_{b}$ & 3.2977 & 3.2423 & 0.9123 \\
\hline \hline EUR & & & \\
$\sigma_{y}$ & 2.0076 & 1.9897 & 1.9876 \\
$\sigma_{\pi}$ & 0.2158 & 0.2333 & 0.2341 \\
$\sigma_{b}$ & 3.6893 & 0.6331 & 0.6324 \\
\hline \hline Union & & & \\
$\sigma_{y}$ & 2.0077 & 1.9881 & 1.9866 \\
$\sigma_{\pi}$ & 0.2165 & 0.2334 & 0.2346 \\
$\sigma_{b}$ & 3.5342 & 0.8492 & 0.6381 \\
\hline \hline
\end{tabular}

Table 3 displays both macroeconomic and financial volatilities to help us understand where the welfare gains come from. We calculate the standard deviations for output, inflation, and borrowing for Spain, the rest of the Euro area, and the whole union (SP and EUR). Our benchmark is the case in which there are no macroprudential policies in place (first column). Then, we see how these volatilities change when we consider the optimized parameters obtained in Table 1 (shown in the second and third columns of Table 3). We can observe that, when the macroprudential policy is introduced in the rest of the Euro area but not in Spain, Spain nevertheless benefits from a more stable economy, in terms of both output and borrowing. This comes at the expense of greater volatility in terms of inflation because of the conflicts that arise between macroprudential and monetary policies, in the context of supply-side shocks. ${ }^{52}$ However, if Spain also implements macroprudential policies, financial stability in Spain improves substantially and, therefore, the stability of the whole union is enhanced. ${ }^{53}$

Thus, when the rest of the Euro area only (not Spain) activates the LTV ratio rule, this region gains in terms of welfare because the new policy delivers greater financial stability, which benefits borrowers. Even though it does not implement the macroprudential measure, Spain also benefits from its Euro

\footnotetext{
${ }^{52}$ See Rubio and Carrasco-Gallego (2015) for a detailed explanation of the policy conflicts.

${ }^{53}$ Creel et al. (2015) find that financial instability has a negative impact on economic performance in the EU. They obtain this result by examining different measures of financial instability.
} 
partners' policy because of the more stable financial scenario created. Furthermore, macroprudential policies usually entail an output cost as they reduce borrowing and the demand coming from constrained individuals is restricted. ${ }^{54}$ Thus, Spain experiences a double gain as it benefits from a more stable financial system overall, without compromising its output. ${ }^{55}$

Then, when we move to the situation in which both regions are implementing macroprudential policies, we see that the gains are larger for the whole union, as well as for each region independently. Now, with Spain contributing to financial stability, borrowers from both regions can benefit. Welfare in the rest of the Euro area increases marginally in this case because the whole union enjoys greater financial stability. This case of coordination between Spain and the rest of the Euro area means welfare in the whole union increases by more than it does in the case where there is no coordination.

\subsection{Impulse Responses}

In this subsection, we present the dynamics of the model with the optimized parameters found in Table 1, as well as those for the benchmark case. That is, we compute impulse responses for three expansionary shocks that generate a credit boom: a productivity shock, a housing demand shock and an expansionary monetary policy shock. These shocks would produce a credit boom in the economy that macroprudential policies can reduce through the activation of the LTV ratio rule. We compare the case in which macroprudential policies are not in place (the benchmark case) with the cases where, first, the optimal macroprudential rule is implemented only in the rest of the Euro area, and second, where it is implemented in the whole area, including Spain.

Figure 1 presents the impulse responses to a technology shock. This is an expansionary shock that makes output increase in a more efficient way, reducing inflation. The expansion that the shock generates in the economy makes borrowing increase, activating the macroprudential rule in the cases in which it is in place. We observe that, for the benchmark case, where there are no macroprudential policies, the LTV ratio stays at its steady state and borrowing increases both in Spain and the rest of the Euro area. However, with macroprudential policies in place, when the credit increase occurs, the LTV ratio decreases to avoid excessive credit growth, which is the aim of the macroprudential regulator. We see that the LTV ratio is cut in Spain only in the case in which macroprudential policies are implemented in

\footnotetext{
${ }^{54}$ Note that this macroprudential policy involves only a short-term output cost because the policy does not represent a change in the steady state. Welfare benefits are long term.

${ }^{55}$ According to the DSGE model simulations presented by Cuerpo et al. (2015), an adjustment in the housing sector of the Spanish economy could have a significant negative impact on economic activity through a decrease in housing investment and consumption.
} 

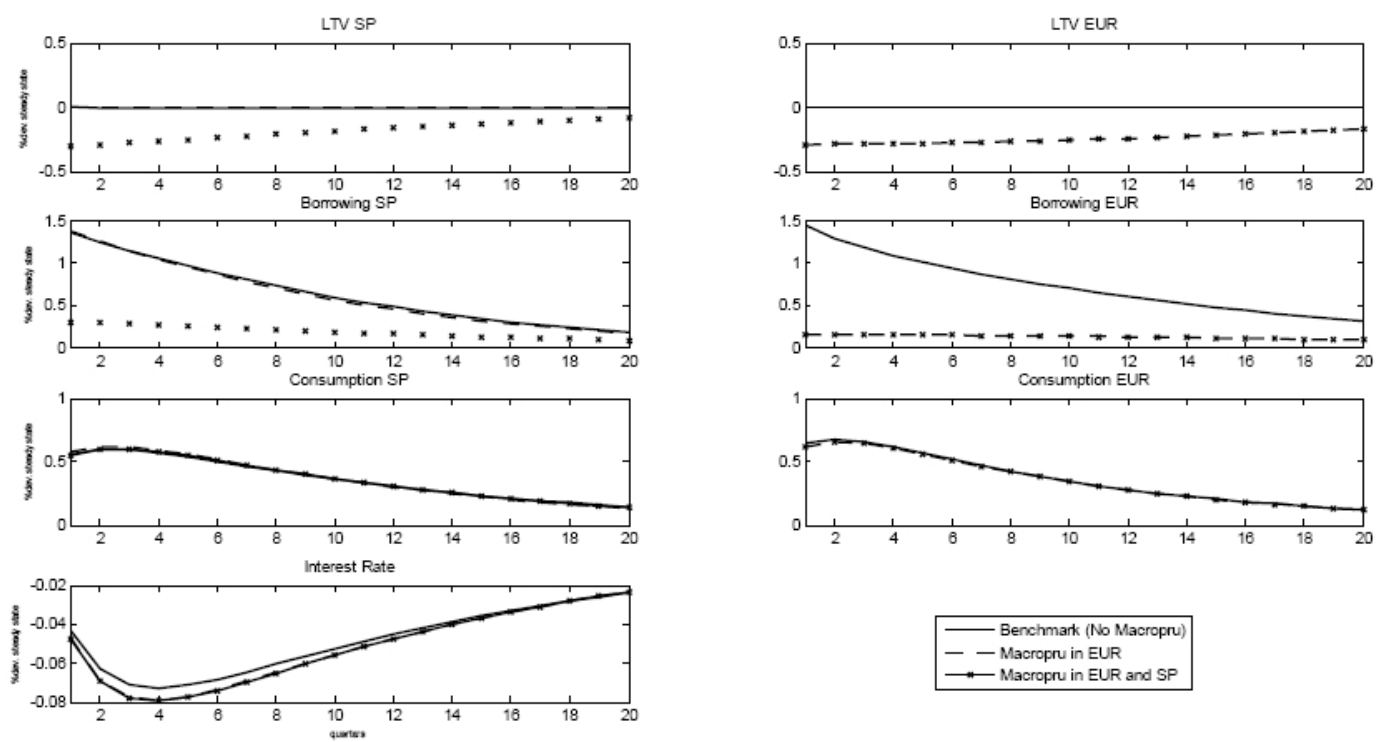

Figure 1: Impulse Responses to a Technology Shock. Optimized parameters for Macroprudential Policies

the whole Euro area, including Spain. In the rest of the Euro area, the LTV ratio decreases regardless of whether Spain implements the policy or not. For the cases in which the macroprudential rule is active and the LTV ratio goes down, we see that credit does not increase as much as it does without the macroprudential rule. Consumption increases in all cases, given the expansionary nature of the shock, but it increases slightly less when the macroprudential policy is in place, representing the output cost that macroprudential policies have, i.e., the fact that they mitigate shocks. When Spain does not implement the LTV ratio rule, but the rest of the Euro area does, Spain benefits from the higher financial stability that the macroprudential policy implies, but it does not experience the output cost, as can be seen from the slightly stronger response of consumption in Spain. The interest rate, which is common to the whole region, decreases because the productivity shock makes inflation fall. The decrease in the interest rate represents an extra expansionary effect, coming from the demand side.

Figure 2 displays impulse responses to a housing demand shock for both Spain and the rest of the Euro area. A housing demand shock is directly translated into a house price increase and it could also be interpreted as a house price shock. As borrowers use housing as collateral, the increase in house prices makes their collateral more valuable. In turn, this makes their borrowing increase, resulting in an expansionary effect on the economy. However, given the differences in the housing preference parameter for both regions, the expansionary effects are stronger in Spain than in the rest of the Euro area. As in the previous case, when the macroprudential policy is active, the LTV ratio decreases, mitigating the 

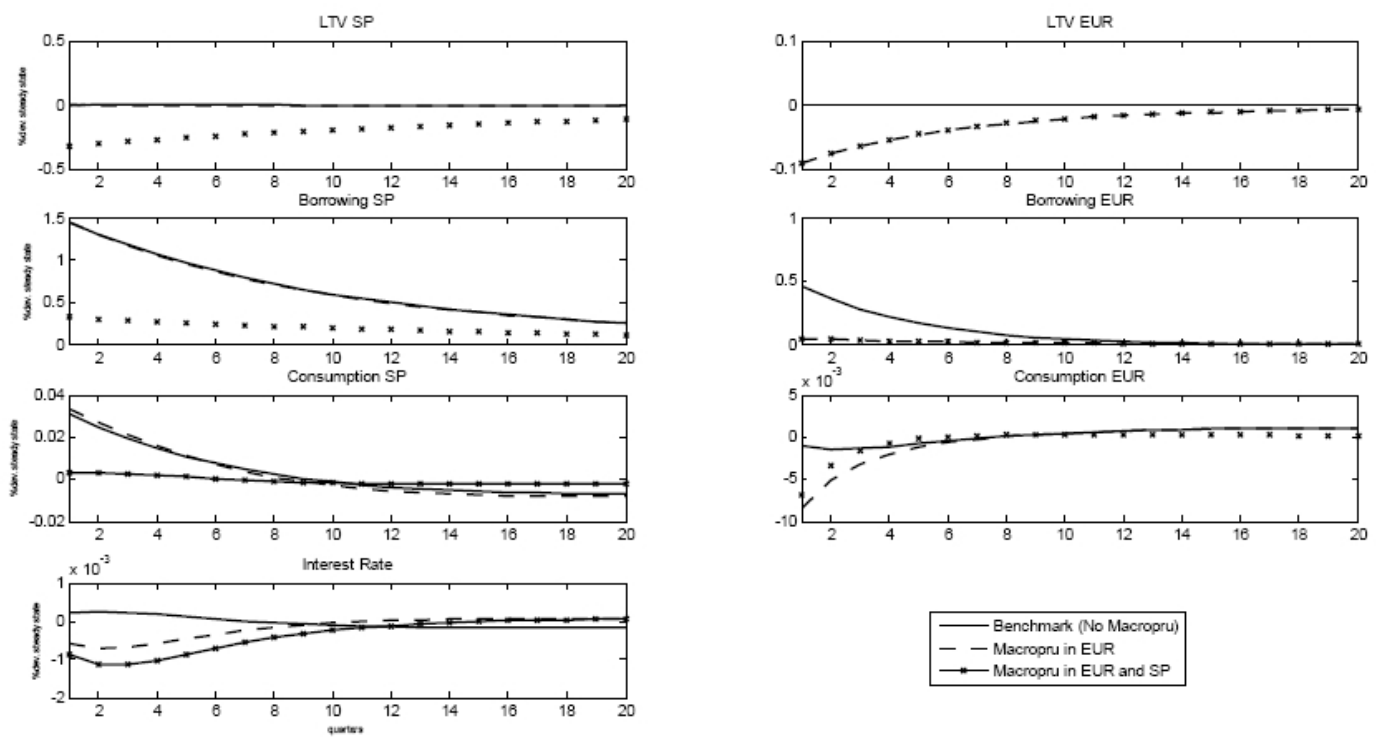
- - Macroprs in EUR $\rightarrow$ Macropru in EUR and SP

Figure 2: Impulse Responses to a Housing Demand Shock. Optimized Parameters for Macroprudential Policies

credit increase. When Spain is not implementing the macroprudential policy, the LTV ratio remains at its steady state and borrowing increases as much as in the benchmark case. Nevertheless, consumption increases slightly more than in the benchmark case, which reflects the fact that there is no output cost in Spain arising from active macroprudential policies, in contrast to the situation in the rest of the Euro area. However, with the macroprudential policy in place for Spain, the output cost becomes evident and consumption increases just marginally for Spain. In the case of the rest of the Euro area, the reduction in the LTV ratio means that borrowing does not increase from the steady state and, thus, there is little reaction to the shock in terms of consumption.

Finally, Figure 3 represents the effects of an expansionary monetary policy shock, i.e., a one standard deviation decrease in the interest rate. Again, this is an expansionary shock that would deliver a credit boom, as in the previous cases. Now, the easiness in credit conditions makes borrowing increase, given that debt repayments will be lower. However, as in the other cases, macroprudential policies make the LTV ratio decrease to avoid an excess in credit growth. As we can observe, when macroprudential policies are in place, the LTV ratio falls, reacting to the credit growth increase. As a consequence, the increase in borrowing is less pronounced when the macroprudential policies are active. The response of output is also slightly mitigated when the macroprudential rule is implemented. 

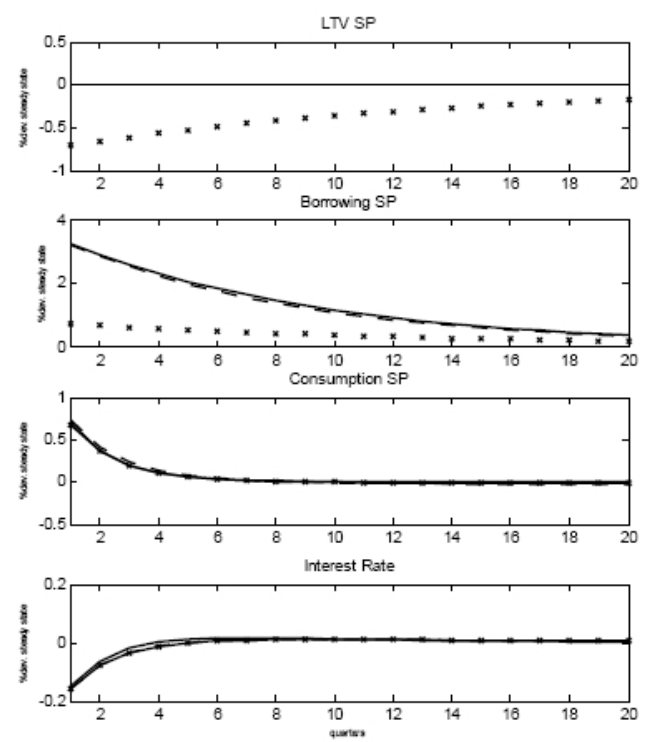
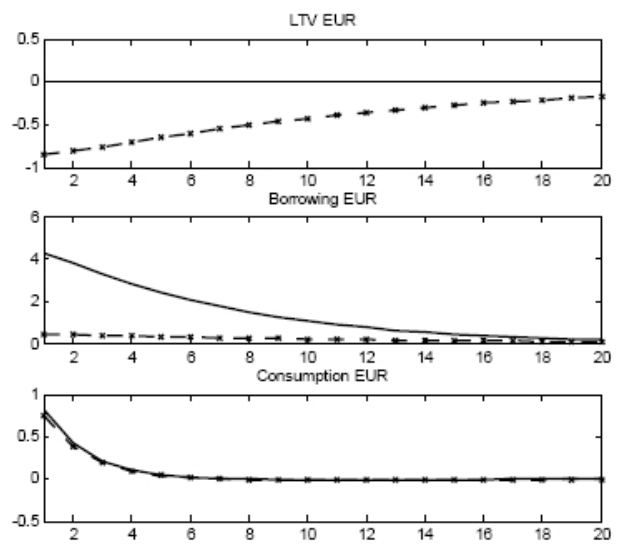

- Benchmark (No Macropru)
- - Macropru in EUR - - Macropru in EUR

Figure 3: Impulse Responses to an Expansionary Monetary Policy Shock. Optimized Parameters for Macroprudential Policies

\section{Concluding Remarks}

In this paper, we explore the implementation of macroprudential policies in the Euro area. Considering that such policies are decided at the national level, we are interested in determining the consequences of a lack of coordination among different countries. We analyze the effects on welfare and financial stability of the fact that one of the countries is not implementing the macroprudential policy (the nocoordination case). Then, we see what happens to the economy when all countries implement the policy (the coordination case).

For this purpose, we build a two-country DSGE model, with housing and collateral constraints to explore the optimal implementation of macroprudential policies in the Euro area. The model distinguishes between the consumption and housing sectors, unconstrained consumers (savers) and constrained consumers (borrowers) and variable and fixed interest rates for borrowers. Monetary policy is operated by the ECB at a centralized level, whereas macroprudential policies, using the LTV ratio as an instrument, are implemented at a national level, as the ESRB recommends.

In particular, we analyze the lack of coordination in macroprudential policies in the Euro area, taking the case of Spain as a natural experiment. Spain is the only country within the EMU that has not commenced the implementation of macroprudential policies and, therefore, it provides a perfect example of our no- coordination case. Therefore, in our model, we calibrate one of the countries to 
represent the Spanish economy, whereas the other country represents the rest of the Euro area.

We find that macroprudential policies, introduced as a countercyclical LTV ratio rule, which responds to credit deviations from the steady state, are welfare enhancing for the monetary union. Welfare gains mainly come from the borrowers' side because this measure promotes financial stability. Savers are worse off because there is a conflict between monetary and macroprudential policy goals. However, total welfare gains are larger when the whole area implements the policy, i.e., when there is coordination across members. When Spain does not apply such macroprudential policies, it still benefits marginally from a more stable financial system, without incurring any output cost. Nevertheless, gains increase when all countries activate the policy.

In terms of dynamics, our results show that when macroprudential policies are active, credit booms generated from expansionary shocks are mitigated. The LTV ratio decreases in those cases and makes borrowing increments lower.

The policy implications of these results are clear: macroprudential policy coordination should be promoted to maximize welfare in the whole monetary union and increase financial stability in all areas. 


\section{Acknowledgements}

This paper was presented at the 47 Annual MMF Conference, the IV Meeting on International Economics, the 7th ReCapNet Conference, the SAEe 2015, the Workshop in Macroprudential Policy, Monetary Policy and Real Economic Activity at the University of Portsmouth, the RES conference and the University of Valencia. The authors wish to thank Anna Samarina and George Bratsiotis for their discussions at the ReCapNet Conference and at the Workshop in Macroprudential Policy, Monetary Policy and Real Economic Activity at the University of Portsmouth, respectively. Special thanks to Javier Suárez, an anonymous referee and the editor of Economic Modelling for their very helpful comments. We are responsible for any remaining errors.

\section{Appendix}

\section{Additional Tables and Figures}

\begin{tabular}{|c|c|c|c|}
\hline \multicolumn{4}{|c|}{ Table A1: Country-Specific Parameter Values } \\
\hline & EUR & SP & \\
\hline$j$ & 0.12 & 0.143 & Weight of Housing in Utility Function \\
\hline$k$ & 0.79 & 0.725 & Average LTV \\
\hline$\alpha$ & 0.43 & 0.91 & Degree of variability of interest rate \\
\hline$n$ & 0.90 & 0.10 & Country size \\
\hline
\end{tabular}




\begin{tabular}{|c|c|c|}
\hline \multicolumn{3}{|c|}{ Table A2: Common Parameter Values } \\
\hline \hline$\beta$ & .99 & Discount Factor for Savers \\
\hline$\widetilde{\beta}$ & .98 & Discount Factor for Savers \\
\hline$\eta$ & 2 & Parameter associated with labor elasticity \\
\hline$\gamma$ & .70 & Labor-Income share for savers \\
\hline$\varepsilon$ & 6 & Elasticity of substitution among intermediate goods \\
\hline $1-\nu$ & 2 & Labor elasticity of substitution across sectors \\
\hline$\rho$ & 0.8 & Interest-rate smoothing in Taylor rule \\
\hline$\phi_{\pi}$ & .5 & Inflation Parameter in Taylor rule \\
\hline$\sigma_{\epsilon}$ & 0.29 & Monetary shock standard error \\
\hline$\rho_{\xi}$ & 0.9 & Technology shock persistence \\
\hline$\rho_{j}$ & 0.95 & Housing Demand shock persistence \\
\hline
\end{tabular}




\section{References}

[1] Akin, O., Montalvo, J., García Villar, L., Peydró, J-L. and Raya, J. (2014), "The Real Estate and Credit Bubble: Evidence from Spain", SERIEs, Spanish Economic Association 5 (2), pp. 223-243.

[2] Andrés, J., Arce, O. and Thomas, C. (2013), "Banking Competition, Collateral Constraints and Optimal Monetary Policy," Journal of Money, Credit and Banking-Supplement to vol. 45 (2), pp. $87-125$.

[3] Ascari, G., and Ropele, T. (2012), "Disinflation in a DSGE Perspective: Sacrifice Ratio or Welfare Gain Ratio?", Journal of Economic Dynamics and Control 36 (2), pp. 169-182.

[4] Aspachs-Bracons, O. and Rabanal, P. (2011), "The Effects of Housing Prices and Monetary Policy in a Currency Union", International Journal of Central Banking 7 (1), pp. 225-274.

[5] Aspachs, O., Rabanal, P. (2010), "The Drivers of Housing Prices in Spain", SERIEs, 1 (1), pp. $101-130$.

[6] Benigno, P. and Woodford, M. (2012), "Linear-Quadratic Approximation of Optimal Policy Problems", Journal of Economic Theory, 147 (1), pp. 1-42.

[7] Banco Bilbao Vizcaya Argentaria (BBVA), (2012), "Dynamic Provisioning: A Buffer Rather Than a Countercyclical Tool?", Working Paper Number 12/22.

[8] Campbell, J., Mankiw, N. G. (1991), "The Response of Consumption to Income: A Cross-Country Investigation", European Economic Review 35 (4), pp. 723-756.

[9] Cerutti, E., Claessens, S., Laeven L. (2016), "The Use and Effectiveness of Macroprudential Policies: New Evidence", Journal of Financial Stability, forthcoming.

[10] Creel, J., Hubert, P., Labondance, F. (2015), "Financial Stability and Economic Performance", Economic Modelling 48, pp. 25-40.

[11] Cuerpo, C., Drumond, I., Lendvai, J., Pontuch, P. and Raciborski, R. (2015), "Private Sector Deleveraging in Europe", Economic Modelling 44, pp. 372-383.

[12] Domeij, D. and Flodén, M. (2006), "The Labor-Supply Elasticity and Borrowing Constraints: Why Estimates are Biased", Review of Economic Dynamics 9, pp. 242-262. 
[13] Draghi, M. (2014), Preface: Flagship Report on Macro-prudential Policy in the Banking Sector, European Systemic Risk Board.

[14] European Central Bank (ECB) (2009), "Housing Finance in the Euro Area", Occasional Paper Series No. 101 / March.

[15] EU (2010), Regulation (EU) No 1092/2010 of the European Parliament and of the Council of 24 November 2010 on European Union Macro-prudential Oversight of the Financial System and Establishing a European Systemic Risk Board.

[16] European Mortgage Federation (2012), Mortgage Interest Rates in the EU.

[17] European Systemic Risk Board (ESRB) (2011), Recommendation of the European Systemic Risk Board (ESRB/2011/3).

[18] ESRB (2014a), ESRB Annual Report 2014.

[19] ESRB (2014b),The ESRB Handbook on Operationalizing Macro-prudential Policy in the Banking Sector.

[20] Funke, M. and Paetz, M. (2012), "A DSGE-Based Assessment of Nonlinear Loan-to-Value Policies: Evidence from Hong Kong", BOFIT Discussion Paper No. 11/2012.

[21] Gerke, R., Jonsson, M., Kliem, M., Kolasa, M., Lafourcade, P., Locarno, A., Makarski, K. and McAdam, P. (2013), "Assessing Macro-Financial Linkages: A Model Comparison Exercise", Economic Modelling 31, pp. 253-264.

[22] Gilchrist, S., Hairault, J. and Kempf, H. (2002), "Monetary Policy and the Financial Accelerator in a Monetary Union", ECB Working Paper 175.

[23] Horvath, M., (2000), ""Sectoral Shocks and Aggregate Fluctuations"," Journal of Monetary Economics 45 (1), pp. 69-106.

[24] Iacoviello, M. (2005), "House Prices, Borrowing Constraints and Monetary Policy in the Business Cycle," American Economic Review 95 (3), pp. 739-764.

[25] Iacoviello, M. and Neri, S. (2010), "Housing Market Spillovers: Evidence from an estimated DSGE Model," American Economic Journal: Macroeconomics, American Economic Association 2 (2), pp. 125-164. 
[26] Iacoviello, M., Smets, F., (2006), House Prices and the Transmission Mechanism in the Euro Area: Theory and Evidence from a Monetary Union Model, mimeo.

[27] IMF (2011), Macroprudential Policy: An Organizing Framework. Prepared by the Monetary and Capital Markets Department.

[28] IMF (2013), Key Aspects of Macroprudential Policy.

[29] Jiménez, G., Ongena, S., Peydró, J. L. and Saurina, J. (2012), "Macroprudential Policy, Countercyclical Bank Capital Buffers and Credit Supply: Evidence from the Spanish Dynamic Provisioning Experiments", Working Papers 628, Barcelona Graduate School of Economics.

[30] Kannan, P., Rabanal, P. and Scott, A. (2012), "Monetary and Macroprudential Policy Rules in a Model with House Price Booms", The B.E. Journal of Macroeconomics, Contributions, vol. 12 (1), 16.

[31] Lambertini, L,. Mendicino, C. and Punzi, M. (2013), "Leaning against boom-bust cycles in credit and housing prices", Journal of Economic Dynamics and Control 37 (8), pp. 1500-1522.

[32] Lawrence, E., (1991), "Poverty and the Rate of Time Preference: Evidence from Panel Data", The Journal of Political Economy 99 (1), pp. 54-77.

[33] McCallum, B. (2001), "Should Monetary Policy Respond Strongly To Output Gaps?", American Economic Review 91 (2), pp. 258-262.

[34] Mendicino, C. and Pescatori, A. (2007), Credit Frictions, Housing Prices and Optimal Monetary Policy Rules, mimeo.

[35] Monacelli, T. (2006), Optimal Monetary Policy with Collateralized Household Debt and Borrowing Constraint, in J. Campbell (ed.) "Monetary Policy and Asset Prices", Conference Proceedings.

[36] Mora-Sanguinetti, J. S. and Rubio, M. (2014), "Recent Reforms in Spanish Housing Markets: An Evaluation using a DSGE Model", Economic Modelling 44 (Supplement 1), pp. S42-S49.

[37] Moro, A. and Nuño, G., (2012), "Does Total-Factor Productivity Drive Housing Prices? A GrowthAccounting Exercise for Four Countries", Economics Letters 115, pp. 221-224.

[38] Ortega, E., Rubio, M. and Thomas, C. (2011), "House Purchase Versus Rental in Spain", Banco de España Working Paper No. 1108. 
[39] Rubio, M. (2011), "Fixed- and Variable-Rate Mortgages, Business Cycles and Monetary Policy", Journal of Money, Credit and Banking 43 (4), pp. 657-688.

[40] Rubio, M. (2014), "Housing Market Heterogeneity in a Monetary Union", Journal of International Money and Finance 40 (C), pp. 163-184.

[41] Rubio, M. and Carrasco-Gallego, J. A. (2013), "Macroprudential Measures, Housing Markets and Monetary Policy", Moneda y Crédito 235, 29-59.

[42] Rubio, M. and Carrasco-Gallego, J. A. (2014), "Macroprudential and Monetary Policies: Implications for Financial Stability and Welfare", Journal of Banking and Finance 49, pp. 326-336.

[43] Rubio, M. and Carrasco-Gallego, J. A. (2015), "Macroprudential and Monetary Policy Rules: A Welfare Analysis", The Manchester School 83 (2), pp. 127-152.

[44] Saurina, J. (2009), "Dynamic Provisioning: The Experience of Spain", Crisis Response: Public Policy for the Private Sector Note 7, Washington: The World Bank Group.

[45] Schmitt-Grohe, S. and Uribe, M. (2004), "Solving Dynamic General Equilibrium Models Using a Second-Order Approximation to the Policy Function", Journal of Economic Dynamics and Control 28 , pp. $755-775$.

[46] Smets, F. and Wouters, R. (2003), "An Estimated Dynamic Stochastic General Equilibrium Model of the Euro Area", Journal of the European Economic Association 1(5), pp. 1123-1175.

[47] Yellen, J. (2010), Macroprudential Supervision and Monetary Policy in the Post-crisis World, Speech at the Annual Meeting of the National Association for Business Economics, Denver, Colorado, October 11. 